\title{
Effect of Pregnancy and Extended Lactation on Milk Production in Dairy Goats Milked Once Daily
}

\author{
A. A. K. Salama, ${ }^{1,2}$ G. Caja, ${ }^{1}$ X. Such, ${ }^{1}$ R. Casals, ${ }^{1}$ and E. Albanell ${ }^{1}$ \\ ${ }^{1}$ Grup de Recerca en Remugants, Departament de Ciència Animal i dels Aliments, Universitat Autònoma de Barcelona, \\ 08193 Bellaterra, Spain \\ ${ }^{2}$ Sheep and Goat Research Department, Animal Production Research Institute, 12311 Dokki, Giza, Egypt
}

\section{ABSTRACT}

Thirty multiparous Murciano-Granadina dairy goats milked once daily were used to study the lactational effects of an extended 24-mo kidding interval (K24; $\mathrm{n}=$ 14) compared with the traditional 12 -mo kidding interval (K12; $\mathrm{n}=16)$. Goats were divided into 2 groups at wk 29 of lactation balanced with respect to parity, milk yield, and somatic cell count. Over a period of $92 \mathrm{wk}$, K12 goats were mated twice, at wk 29 during the first lactation and at wk 79 during the second lactation, whereas K24 goats were mated once, at wk 79 of extended first lactation. The K12 goats were dried off from wk 14 to 21 of pregnancy (wk 43 to 50 of lactation). Milk yield was recorded from wk 2 to 92 , and milk composition was studied from wk 29 to 92 . Milk fatty acids were analyzed in milk samples taken at wk 39 (wk 10 of pregnancy) and 55 (wk 5 of subsequent lactation), when milk in udder compartments (cisternal and alveolar) was also evaluated. Average milk yield during the first 29 wk was $2.23 \pm 0.13 \mathrm{~L} / \mathrm{d}$. Pregnancy reduced milk yield in K12 goats from wk 39 to 42 of lactation compared with K24 goats. During the dry period for $\mathrm{K} 12$ goats, milk yield of K24 goats averaged $1.53 \pm 0.10$ L/d. From wk 51 to 79 , K12 goats produced $32 \%$ more milk than did K24 goats, but their milk contained lower fat and protein than that of K24 goats. No changes were detected for milk lactose and somatic cell count from wk 51 to 79 . From wk 80 to 92 , differences in milk yield and milk composition between groups were not significant. Milk of pregnant $\mathrm{K} 12$ goats contained higher $\mathrm{C}_{16: 1}$ and conjugated $\mathrm{C}_{18: 2}$ fatty acids, and had a higher desaturase index than milk of open K24 goats at wk 39. In the following lactation (wk 55), milk of $\mathrm{K} 12$ goats contained higher $\mathrm{C}_{18: 2}$ and $\mathrm{C}_{18: 3}$, and lower $\mathrm{C}_{16: 0}$ fatty acids, resulting in a lower atherogenicity index compared with K24 goats. Cisternal milk at wk 39 was lower for K12 than K24 goats, whereas alveolar milk did not differ. In K12 goats, values of cisternal

Received March 1, 2005.

Accepted July 14, 2005.

Corresponding author: G. Caja; e-mail: Gerardo.caja@uab.es. milk tripled, but alveolar milk only doubled at wk 55 (wk 5 of subsequent lactation) compared with wk 39, indicating the importance of the cistern in accommodating high milk yield in early lactation. Values of cisternal and alveolar milk did not differ between wk 39 and 55 for K24 goats. Fat content was higher for alveolar milk than cisternal milk for K12 goats at wk 55 and for K24 goats at wk 39 and 55 . No differences in milk protein or lactose were detected between cisternal and alveolar milk. In conclusion, pregnancy reduced milk yield from wk 10 after conceiving onwards. Extended lactation did not significantly decrease milk yield $(-8.2 \%)$, but increased milk components that may contribute to cheese yield, and may be a useful strategy for reducing metabolic stress in early lactation and for simplifying herd management in dairy goats.

(Key words: pregnancy, extended lactation, cisternal and alveolar milk, dairy goat)

Abbreviation key: CLA = conjugated linoleic acid ( cis9,trans-11 isomer), FA = fatty acids, K12 = 12-mo kidding interval, K24 = 24-mo kidding interval, $\mathbf{T} \mathbf{J}=$ tight junctions.

\section{INTRODUCTION}

Pregnancy has been shown to cause a significant decline in milk yield of dairy cows due to hormonal changes (Bachman et al., 1988; Akers, 2002) and the nutritive requirements of the fetus, especially during the third part of gestation (Bell et al., 1995). Some researchers (Olori et al., 1997; Brotherstone et al., 2004) reported milk yield losses in dairy cows from 5 mo of pregnancy onwards, whereas others (Bormann et al., 2002) reported an earlier decline. In the only available report on lactational effects of pregnancy in dairy goats mated at peak of lactation (Knight and Wilde, 1988), milk yield decreased at the same rate in pregnant goats during the first 8 wk of pregnancy as in nonpregnant goats. Nevertheless, milk yield decreased more quickly in the pregnant goats thereafter, reaching $57 \%$ of the milk yield of nonpregnant goats in the last week before parturition. No information on the effects of pregnancy on milk composition and milk partitioning in the udder 
was reported in the study of Knight and Wilde (1988). Moreover, the influence of pregnancy on milk production in late lactation (as in the case of dairy cows) has not been reported before in goats.

Extended lactation in dairy cows is an alternative to the typical 300-d lactation. It reduces the number of dry days within the animal's lifetime and the metabolic stress related to negative energy balance during early lactation (Knight, 1997), and may be profitable for dairy farmers (Arbel et al., 2001). Linzell (1973) observed that well-fed nonpregnant goats, milked twice daily, can lactate continuously for 2 to $4 \mathrm{yr}$. There is no information on the quality of milk produced from goats under extended lactation.

The objective of this study was to investigate the lactational effects of 2 kidding intervals, producing a typical 12-mo lactation cycle in contrast to an extended lactation cycle of $24 \mathrm{mo}$ in Murciano-Granadina dairy goats milked once daily. Effects of pregnancy on lactation were also evaluated.

\section{MATERIALS AND METHODS}

The experimental procedures and animal care conditions were approved by the Ethical Committee of Animal and Human Experimentation of the Universitat Autònoma de Barcelona (reference CEEAH 02/400).

\section{Animals and Management Conditions}

Thirty multiparous Murciano-Granadina dairy goats located on the experimental farm of the S1GCE (Servei de Granges i Camps Experimentals) of the Universitat Autònoma de Barcelona in Bellaterra were used after fall kidding during the second week of October. Murciano-Granadina goats are usually bred for an annual kidding and have a wide reproduction season in Spain (Falagan, 1988), with a shallow seasonal anestrus from February to June, and frequent out-of-season kidding for producing Christmas milk kid ('cabrito lechal').

Goats were divided into 2 balanced groups at wk 29 of lactation with respect to parity, milk yield (recorded from wk 2 to 29), and SCC (recorded on 2 consecutive days in wk 29). The groups were: traditional 12-mo kidding interval (K12; $\mathrm{n}=16)$, where goats were impregnated twice at wk 29 and 79 of the study and dried off twice from wk 43 to 50 following first lactation and from wk 93 to 100 after the second lactation; and extended 24-mo kidding interval (K24; $\mathrm{n}=14)$, where goats were impregnated once at wk 79 and dried off once from wk 93 to 100 . The average litter size in the previous kidding was $2.12 \pm 0.15$ and $2.23 \pm 0.20$ kids/ goat for the K12 and K24 groups, respectively. Mating was carried out in April at wk 29 and 79 after natural induction of estrus by the buck effect without light treatment. A teaser buck was introduced for $4 \mathrm{~d}$ and then replaced by a fertile one that impregnated $82 \%$ of goats between $\mathrm{d} 5$ and 9 of introduction.

During a 2-yr period, K12 goats had 2 lactations (from wk 1 to 42 and from wk 51 to 92), whereas K24 goats had 1 extended lactation (from wk 1 to wk 92). The period from wk 30 to 42 allowed us to study the effect of pregnancy on milk production in K12 pregnant goats compared with K24 open goats.

Goats grazed for $6 \mathrm{~h} / \mathrm{d}$ in an annual Italian ryegrass prairie and were supplemented in the shelter with 0.5 to $1.0 \mathrm{~kg} / \mathrm{d}$ of a commercial concentrate $(1.53 \mathrm{Mcal}$ of $\mathrm{NE}_{\mathrm{I}} / \mathrm{kg} ; 16 \% \mathrm{CP}$, as fed) according to lactation stage, and with $0.5 \mathrm{~kg} / \mathrm{d}$ of alfalfa pellets. During the dry period (wk 43 to 50), goats were kept in pens. Their individual daily ration consisted of a dehydrated mixture of whole-plant corn and alfalfa hay (1:1) fed ad libitum, $0.2 \mathrm{~kg}$ of whole barley grain, $0.3 \mathrm{~kg}$ of alfalfa pellets, and $0.5 \mathrm{~kg}$ of concentrate pellets.

Goats were milked once daily at $0900 \mathrm{~h}$ in a double-12 stall Casse system parallel milking parlor (WestfaliaSurge Ibérica, Granollers, Spain) with recording jars (2 $\mathrm{L} \pm 5 \%)$ and low milk pipeline. Typical milking settings (vacuum $=42 \mathrm{kPa}$; pulsation rate $=90$ pulses $/ \mathrm{min}$; and pulsation ratio $=66 \%$ ) for goats of this breed were used (Salama et al., 2004). Milking routine included machine milking without udder preparation or teat cleaning, machine stripping, and teat dipping in an iodine solution (P3-cide plus, Henkel Hygiene, Barcelona, Spain).

\section{Procedures, Sample Collection, and Analysis}

Milk yields of individual goats were recorded weekly by using the recording jars in the milking parlor throughout the experiment. Milk composition and SCC were recorded biweekly from wk 29 to 41 and monthly thereafter. A sample of approximately $50 \mathrm{~mL}$ was placed in a plastic vial, preserved with an antimicrobial tablet (Bronopol, Broad Spectrum Microtabs II, D\&F Control Systems Inc., San Ramon, CA), and stored at $4^{\circ} \mathrm{C}$ until analysis. Milk fat, protein, lactose, and SCC were determined in the Dairy Herd Improvement laboratory of Catalonia (Allic, Cabrils, Barcelona, Spain) using infrared spectroscopy and an automated somatic cell counter (MilkoScan 4000 + Fossomatic 5000, Foss Electric, Hillerød, Denmark).

During wk 39 and 55 (wk 10 of pregnancy and wk 5 of the subsequent lactation, respectively for K12 goats), a 50-mL milk sample from K12 and K24 goats was collected, immediately cooled, the fat fraction separated by centrifugation for $30 \mathrm{~min}$ at $6000 \times \mathrm{g}$ and $4^{\circ} \mathrm{C}$, and then stored at $-80^{\circ} \mathrm{C}$. Methylation of fatty acids (FA) was performed according to Sukhija and Palmquist 
Table 1. Lactational performances of dairy goats according to kidding interval and physiological stage during the 92-wk experimental period (data are least squares means $\pm \mathrm{SE}$ ).

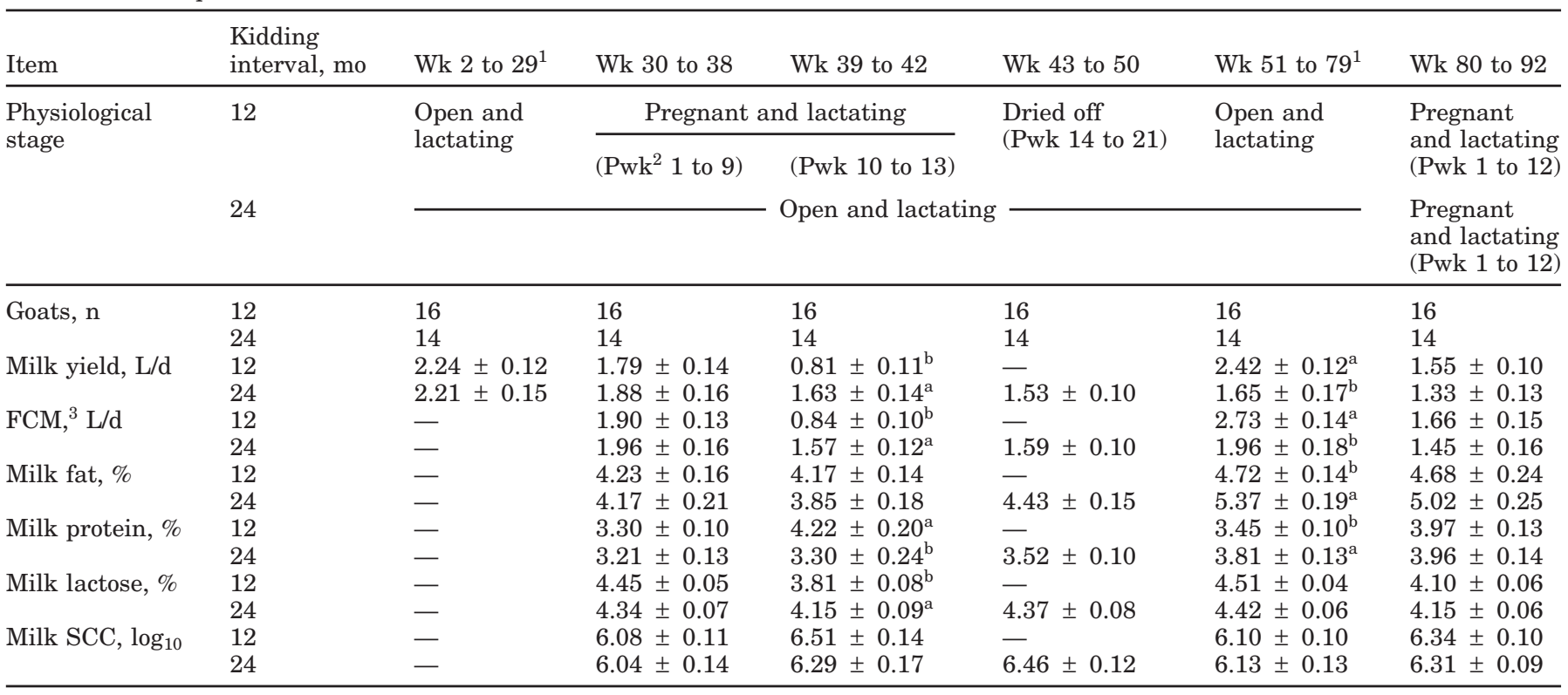

${ }^{\mathrm{a}, \mathrm{b}}$ Means with different superscripts within the same column for each variable are different $(P<0.05)$.

${ }^{1}$ Start of mating at wk 29 and 79.

${ }^{2} \mathrm{Pwk}=$ Week of pregnancy.

${ }^{3} \mathrm{FCM}=0.4(\mathrm{~L}$ of milk $)+15$ (kg fat).

(1988) and the modifications of Kramer et al. (1997). Fatty acid methyl esters were analyzed by gas chromatography (HP 6890, Agilent Technologies, Palo Alto, $\mathrm{CA})$ using a gas chromatograph equipped with a flameionization detector and HP-23 (cis/trans FAME) capillary column $(60 \mathrm{~m} \times 0.25 \mathrm{~mm}$ i.d. with $0.25-\mu \mathrm{m}$ film thickness; Agilent Technologies). Initial temperature was $40^{\circ} \mathrm{C}$ (for $6 \mathrm{~min}$ ) increased to $230^{\circ} \mathrm{C}$ (for $12 \mathrm{~min}$ ) at a rate of $5^{\circ} \mathrm{C} / \mathrm{min}$. Individual $\mathrm{FA}$ were identified by comparison of retention times to those of pure standards (Sigma-Aldrich Química, Madrid, Spain) and expressed as percentages of the total FA detected as fatty acid methyl esters.

Milk partitioning in the udder (cisternal and alveolar) of K12 and K24 goats was determined at wk 39 and 55. To prevent undesired milk letdown during evaluation of milk partitioning in the udder, all goats received $0.8 \mathrm{mg}$ (i.v.) of atosiban (Tractocile, Ferring, Spain), an oxytocin receptor-blocking agent, while in their pens (Salama et al., 2004). Thereafter, goats were taken to the milking parlor and machine-milked to evacuate cisternal milk. Approximately $20 \mathrm{~min}$ after the atosiban injection, goats received $2 \mathrm{IU}$ (i.v.) of oxytocin (Laboratorios Ovejero, León, Spain) and machinemilked to obtain the letdown alveolar milk. Samples of cisternal and alveolar milk were taken for the analysis of fat, protein, lactose, and SCC as previously described.

\section{Statistical Analyses}

Data were analyzed by ANOVA using the PROC MIXED for repeated measurements (version 8.2; SAS Inst., Inc., Cary, NC). The statistical mixed model contained the fixed effects of treatment (K12 or K24), week of lactation, and parity, the random effect of animal within treatment, the interactions between treatment and week of lactation and between treatment and parity, and the residual error. For data analyses of milk fraction composition, the fixed effect of fraction (cisternal or alveolar) and the triple interaction for treatment, week of lactation, and fraction were added to the model. Logarithmic transformations $\left(\log _{10}\right)$ of SCC values were used in the statistical analyses.

\section{RESULTS AND DISCUSSION}

\section{Milk Yield}

Average data of milk yield and milk composition, and milk yield changes throughout the experiment (92 wk) are shown in Table 1 and Figure 1. Milk yield before conception (wk 2 to 29 of lactation) and during the first 7 wk of pregnancy (wk 30 to 36 of lactation) was similar for K12 and K24 goats, and averaged $2.15 \pm 0.14 \mathrm{~L} / \mathrm{d}$. Milk yield of K12 goats tended to be lower than that of K24 goats at wk $8(1.52 \pm 0.14$ vs. $1.80 \pm 0.18 \mathrm{~L} / \mathrm{d} ; P=$ 


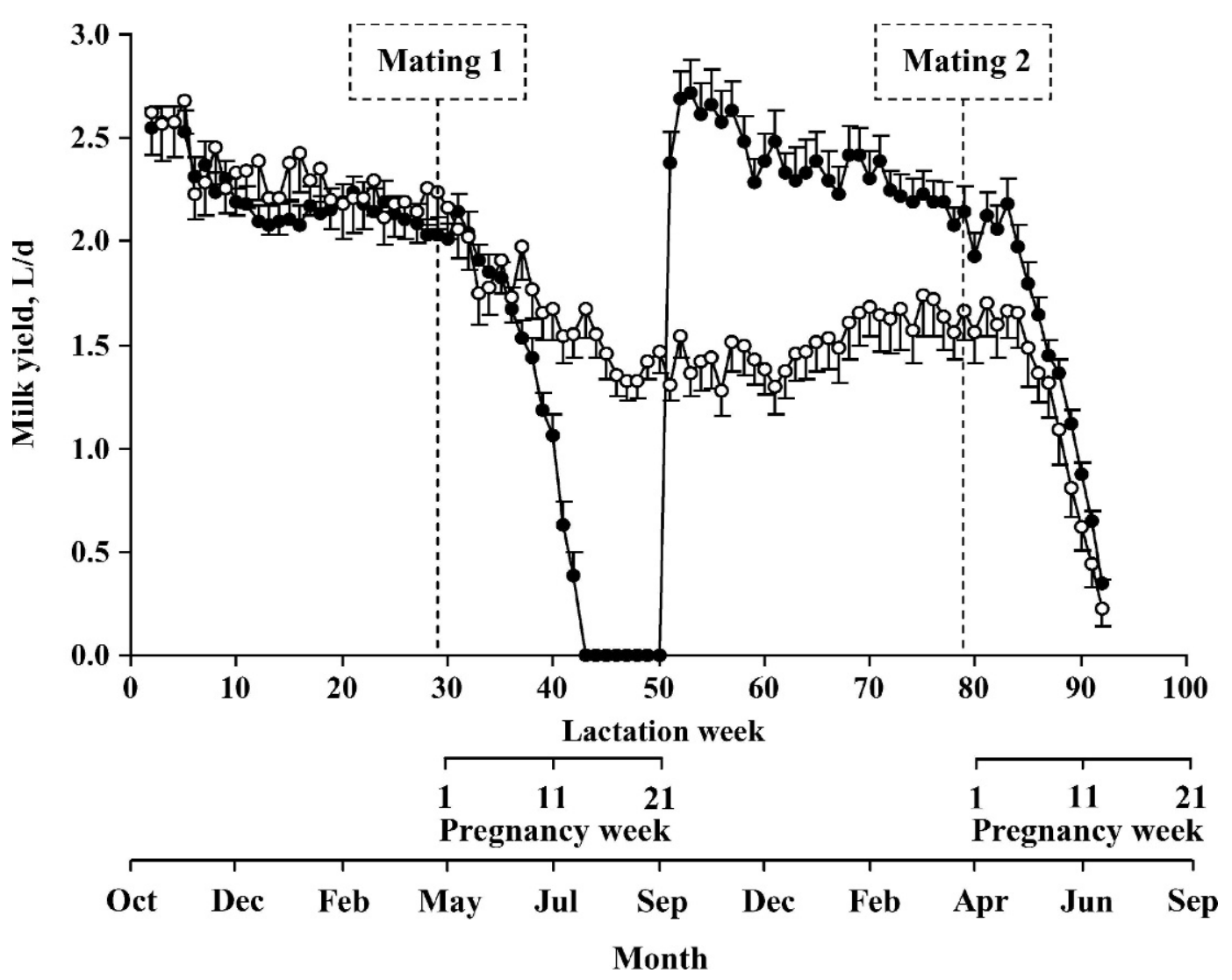

Figure 1. Daily milk yield in dairy goats kidded annually $(\bullet)$ or biennially $(\bigcirc)$. Values are means with SE indicated by vertical bars.

$0.068)$ and wk $9(1.38 \pm 0.14$ vs. $1.65 \pm 0.18 \mathrm{~L} / \mathrm{d} ; P=$ 0.114) of pregnancy. However, the influence of pregnancy started to be significant $(P<0.05)$ in $\mathrm{K} 12$ goats at wk 10 of pregnancy (wk 39 of lactation). Milk yield losses were $0.32(P<0.05), 0.51(P<0.001), 0.85(P<$ $0.001)$, and $1.11(P<0.001) \mathrm{L} / \mathrm{d}$ at wk $10,11,12$, and 13 of pregnancy, respectively, representing approximately a 1.5-fold increase in the rate of decline each week over that period. Knight and Wilde (1988) reported that pregnancy had no effect on milk yield during the first 8 wk of pregnancy in Saanen goats, but milk yield decreased rapidly thereafter and was $57 \%$ of the value of nonpregnant goats in the last week of pregnancy. Milk yield in K12 goats at wk 13 of pregnancy (wk 42 of lactation) was only $21 \%$ of the value of K24 goats $(0.31 \pm 0.09$ vs. $1.41 \pm 0.14 \mathrm{~L} / \mathrm{d} ; P<0.001)$. In our experiment, goats were milked once daily and mated relatively late in lactation (wk 29), which might explain the greater milk yield losses compared with the experiment of Knight and Wilde (1988) in which goats were milked twice daily and mated much earlier than in our study (wk 8). The greater effect of pregnancy on late lactation may be due to the decreasing power of galactopoietic hormones as lactation advanced. Sorensen and
Knight (2002) reported that blood concentration of GH decreased whereas insulin concentration increased as lactation advanced in dairy cows. Pregnancy also caused a significant decline in milk yield of dairy cows in late lactation from mo 5 of gestation onwards (Olori et al., 1997; Brotherstone et al., 2004) or from as early as mo 3 of pregnancy (Bormann et al., 2002).

The mechanism by which pregnancy influences milk yield is not fully understood, but it is believed to be caused by the hormones released during pregnancy, most probably estrogen (Bachman et al., 1988; Akers, 2002). Administration of estrogen caused mammary gland regression with a significant decline in milk yield in lactating goats (Peaker and Linzell, 1974). Moreover, estradiol injection before drying off accelerated mammary tissue involution in dairy cows (Athie et al., 1997) and goats (Mellado et al., 1998) by promoting plasminogen activation (Athie et al., 1997). Circulating estradiol is low until wk 9 of pregnancy in goats, increases gradually until $1 \mathrm{wk}$ before kidding, and then peaks before kidding (Dhindsa et al., 1981). Estradiol concentration during pregnancy is proportional to the number of fetuses (Dhindsa et al., 1981; Manalu et al., 1996). Litter size in K12 goats averaged $2.2 \pm 0.1$ kids/goat, which is 
relatively high for goats (Amoah et al., 1996), indicating that a marked effect of estrogen on milk secretion must have occurred. In addition to estrogen, placental lactogen peaks during the last third of pregnancy and may influence mammogenesis and lactogenesis, and alter the maternal metabolism to accommodate the growth and development of the fetus (Akers, 2002).

In addition to the hormonal effect, yield losses might be due to the nutritive requirements of the gravid uterus. Energy requirements for pregnancy not only include the energy deposited in the conceptus, but also the energy used for the conceptus metabolism and the energy used by maternal tissues to support the conceptus (Freetly and Ferrell, 1998). In the current study, we found a negative correlation $\left(\mathrm{R}^{2}=0.35 ; P<0.05\right)$ between litter birth weight and milk yield at wk 13 of pregnancy (wk 42 of lactation) before drying off (data not shown), which may indicate the competition for energy between milk production and conceptus. Glucose is the main source of energy for the gravid uterus, and an increase in the net hepatic plasma glucose release in pregnant ewes has been reported from $d 40$ of pregnancy onwards (Freetly and Ferrell, 1998). Despite this hepatic release of glucose, pregnant goats had lower concentrations of blood glucose than did nonpregnant goats after d 84 of pregnancy (Khan and Lurdi, 2002). This suggests that there may be competition for glucose between the mammary gland (for lactose synthesis) and the gravid uterus (especially with twins or triplets), which would result in milk yield losses during pregnancy.

From wk 43 to 50, K12 goats were dried off whereas K24 goats produced $1.53 \pm 0.10 \mathrm{~L} / \mathrm{d}$ (Table 1 and Figure 1). From wk 51 to 92 , milk yield of K12 goats peaked $(2.67 \pm 0.15 \mathrm{~L} / \mathrm{d}$ ) between wk 53 and 55 (wk 3 and 5 of subsequent lactation) and then declined gradually $(P<$ $0.05)$, whereas milk yield in K24 goats tended $(P<0.10)$ to increase at wk 68 of lactation from $1.43 \pm 0.14$ to $1.65 \pm 0.16 \mathrm{~L} / \mathrm{d}$ (Figure 1). This increase in milk yield of K24 goats was maintained throughout spring when grass quality and photoperiod were increasing. A longer photoperiod is related to increases in circulating prolactin in goats (Kornalijnslijper et al., 1997), and prolactin and IGF-I in dairy cows (Dahl and Petitclerc, 2003). In accordance with our results, nonpregnant goats continued to lactate for 2 to $4 \mathrm{yr}$ and had a rise in milk yield in the spring either when they were grazing (Mackenzie, 1967) or when they were kept housed under a constant photoperiod of $16 \mathrm{~h}$ light/d and temperature and given dry feeds (Linzell, 1973). It is not clear why the positive effect of longer daylight was more evident in K24 goats than in K12 goats. From wk 51 to 79 (wk 1 to 29 of subsequent lactation), K12 goats produced $32 \%$ more milk $(P<0.001)$ than K24 goats; this difference de- creased to $28 \%$ when milk yield was corrected for fat content, but the difference was still significant $(P<$ 0.01) as shown in Table 1. Differences in milk yield between groups were maintained until wk 85 and were not significantly different thereafter (Figure 1). Nevertheless, from wk 80 to 92 (wk 30 to 42 of subsequent lactation), no differences were detected between K12 and K24 goats for milk yield $(P=0.151)$ and FCM (Table 1).

In the 92-wk experimental period, K12 and K24 goats produced a similar total milk yield $(1192 \pm 58 \mathrm{~L}$ and $1093 \pm 73 \mathrm{~L}$, respectively; $P=0.319$ ). No significant losses in milk yield were reported either in dairy cows when the calving interval was extended from 12 to 14 (Arbel et al., 2001), or 16 mo (Osterman and Bertilsson, 2003). The K24 goats lost the kid crop of $1 \mathrm{yr}$. The reduced income in K24 goats was partially compensated by the greater price of the milk produced between wk 51 and 79 which was richer in fat and protein than that of K12 goats (Table 1). Moreover, the biennial kidding system with extended lactation may be a good alternative for goats that remain open after mating in the first year, and those could be remated with their counterparts in the second year.

Goats were mated at wk 79 (wk 29 of subsequent lactation) and all became pregnant and kidded at d 158 $\pm 1.9 \mathrm{~d}$ after the start of mating, indicating that both goat groups were in adequate condition for reproduction. Similarly, Ratnayake et al. (1998) reported no differences in fertility among dairy cows managed for calving intervals of 12,15 , or $18 \mathrm{mo}$.

\section{Milk Composition and SCC}

Values of milk fat, protein, lactose, and $\log _{10}$ SCC did not differ between K12 and K24 goats from wk 30 to 38 of lactation (Table 1). However, differences were detected at wk 41 (wk 12 of pregnancy), when milk yield of K12 goats was low and tended to contain more fat $(4.63 \pm 0.18$ vs. $3.86 \pm 0.21 \% ; P<0.10)$, more protein $(4.89 \pm 0.16$ vs. $3.43 \pm 0.19 \% ; P<0.001)$, and less lactose $(3.58 \pm 0.10$ vs. $4.23 \pm 0.12 \% ; P<0.001)$ than milk from K24 goats (Figure 2). Leakiness of tight junctions (TJ) during advanced pregnancy may account for milk composition differences between K12 and K24 goats. Elevated levels of progesterone induce TJ leakiness, and the injection of a progesterone antagonist in mice in late pregnancy resulted in a rapid closure of TJ (Nguyen et al., 2001). The highest level of circulating progesterone was reported to be between wk 8 (when placenta is functional) and wk 17 of pregnancy in goats (Kornalijnslijper et al., 1997), and was proportional to the number of fetuses (Manalu et al., 1996). Thus, elevated pro- 


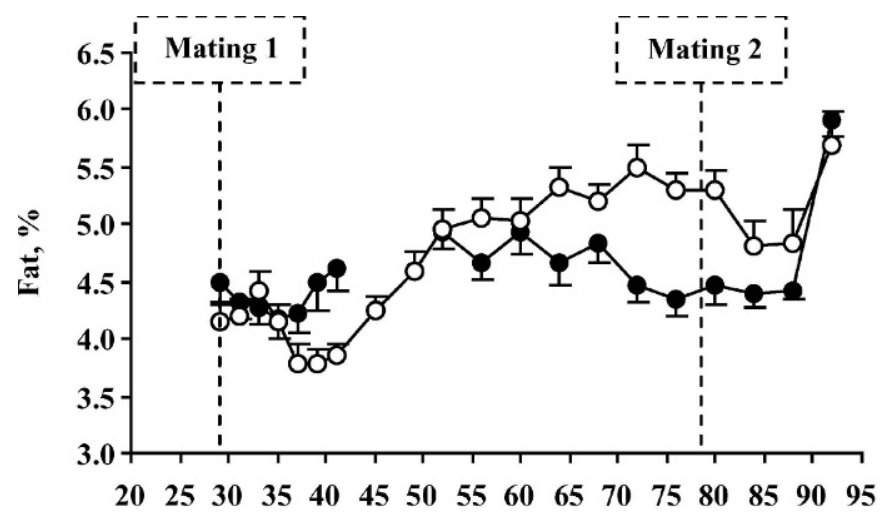

Lactation week

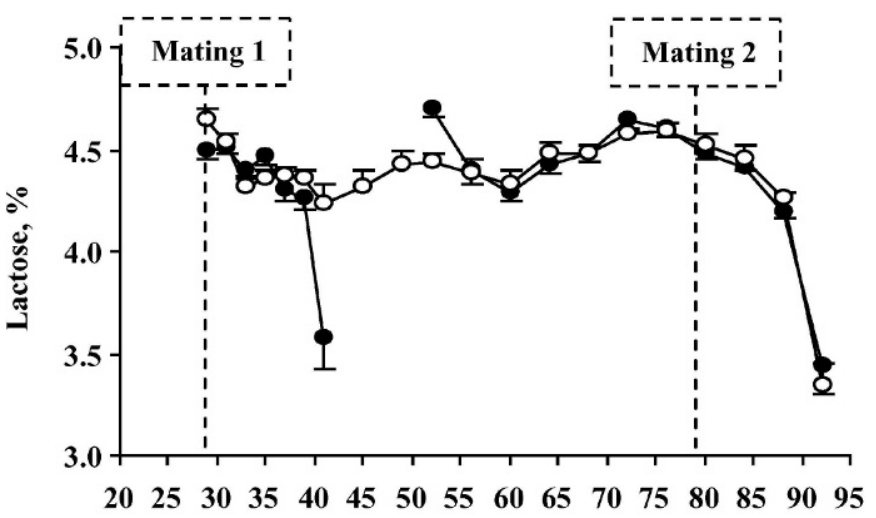

Lactation week

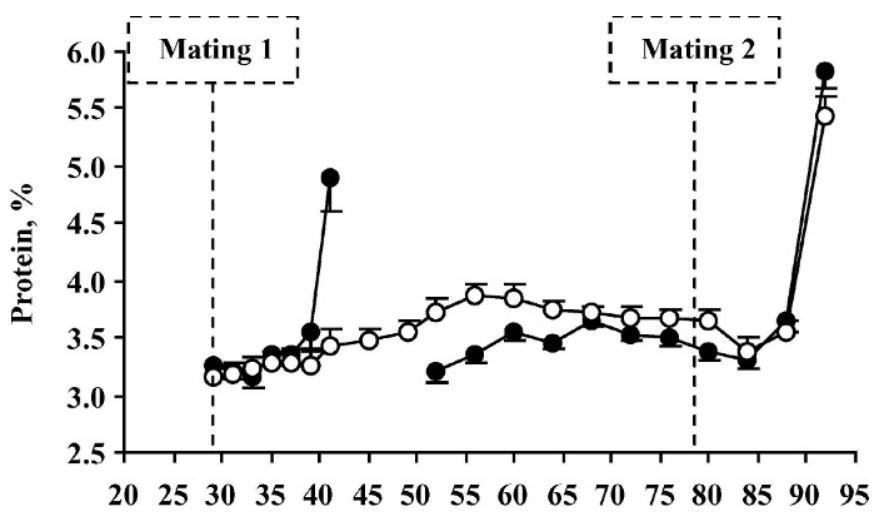

Lactation week

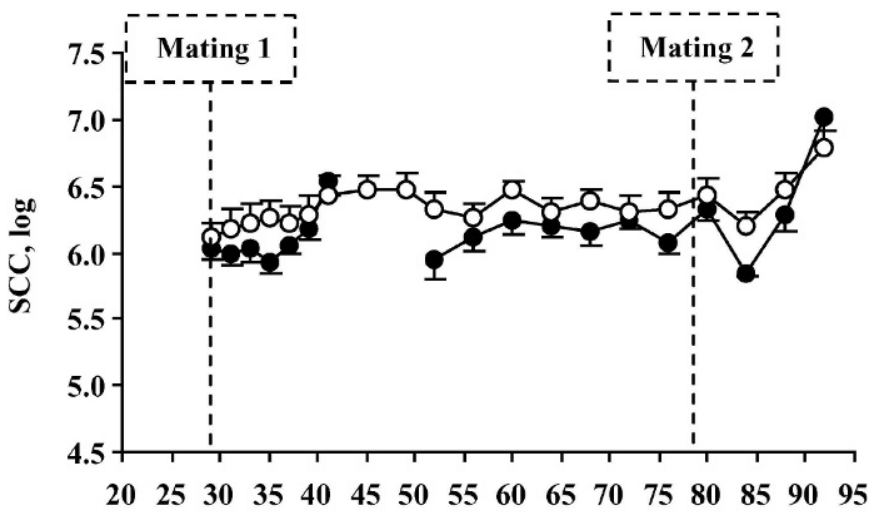

Lactation week

Figure 2. Milk fat, protein, lactose, and SCC in dairy goats kidded annually $(\bullet)$ or biennially (O). Values are means with SE indicated by vertical bars.

gesterone concentrations during advanced pregnancy may favor TJ leakiness.

Comparing wk 2 and 12 of pregnancy (wk 31 and 41 of lactation), increases $(P<0.001)$ in milk fat $(4.32 \pm$ 0.13 to $4.63 \pm 0.20 \%)$, milk protein $(3.21 \pm 0.08$ to 4.89 $\pm 0.28 \%)$, and $\log _{10} \operatorname{SCC}(5.98 \pm 0.08$ to $6.55 \pm 0.11)$ were detected in K12 goats, whereas milk lactose decreased $(P<0.001)$ from $4.51 \pm 0.03$ to $3.58 \pm 0.15 \%$ (Figure 2 ). Similarly, increases in milk fat and protein contents, and a decrease in lactose content were observed in dairy cows in late pregnancy at the end of lactation (Remond et al., 1992; Olori et al., 1997). Changes in milk composition before drying off in K12 goats may be the result of TJ leakiness, thus reducing milk secretion and allowing the flow of plasma proteins into the alveolar lumen (Nguyen et al., 2001). Leaky TJ may also result in lactose loss from milk to plasma (Stelwagen et al., 1995), which may explain the low content of milk lactose at wk 12 of pregnancy.
During the first 29 wk of the subsequent lactation (wk 51 to 79), milk from K12 goats contained less $(P<$ $0.05)$ fat $(-14 \%)$ and protein $(-10 \%)$ than did milk from K24 goats (Table 1 and Figure 2). The lower fat and protein contents in milk of K12 goats is probably due to a dilution effect as their milk yield was greater than K24 goats. Moreover, the negative energy balance at early lactation in K12 goats (see below) could lead to a lower percentage of protein as previously reported in dairy cows (Remond et al., 1992). From wk 51 to 79 (wk 1 to 29 of subsequent lactation), no differences $(P>$ $0.10)$ between groups were detected for milk lactose and SCC (Table 1 and Figure 2). Lactose is the major osmotic regulator of milk, and a strong positive correlation exists between lactose synthesis and milk yield. Knight and Wilde (1993) found that the number of secretory cells in the udder of goats decreased as lactation advanced, but cell activity remained unchanged. Reduced milk yield without reduced lactose content in 
Table 2. Effect of kidding interval and lactation stage on fatty acid composition of milk fat in dairy goats (data are least squares means of percentages of total methyl esters).

\begin{tabular}{|c|c|c|c|c|c|}
\hline & \multicolumn{4}{|c|}{ Kidding interval, mo } & \multirow[b]{3}{*}{ SEM } \\
\hline & \multicolumn{2}{|c|}{12} & \multicolumn{2}{|c|}{24} & \\
\hline & Wk $39^{1}$ & Wk $55^{2}$ & Wk 39 & Wk 55 & \\
\hline Goats, $\mathrm{n}$ & 16 & 16 & 14 & 14 & \\
\hline \multicolumn{6}{|l|}{ Fatty acid } \\
\hline $\mathrm{C}_{4: 0}$ & 0.94 & 1.01 & 1.00 & 0.94 & 0.04 \\
\hline $\mathrm{C}_{6: 0}$ & $1.12^{\mathrm{b}}$ & $1.45^{\mathrm{a}}$ & $1.23^{\mathrm{b}}$ & $1.25^{\mathrm{b}}$ & 0.07 \\
\hline $\mathrm{C}_{8: 0}$ & $2.12^{\mathrm{b}}$ & $2.77^{\mathrm{a}}$ & $2.26^{\mathrm{b}}$ & $2.24^{\mathrm{b}}$ & 0.11 \\
\hline $\mathrm{C}_{10: 0}$ & $9.34^{\mathrm{b}}$ & $10.86^{\mathrm{a}}$ & $9.74^{\mathrm{b}}$ & $9.68^{\mathrm{b}}$ & 0.37 \\
\hline $\mathrm{C}_{10: 1}$ & 0.20 & 0.18 & 0.14 & 0.21 & 0.05 \\
\hline $\mathrm{C}_{12: 0}$ & 5.09 & 5.30 & 4.81 & 5.00 & 0.36 \\
\hline $\mathrm{C}_{14: 0}$ & $11.31^{\mathrm{a}}$ & $10.33^{\mathrm{b}}$ & $10.67^{\mathrm{ab}}$ & $10.76^{\mathrm{ab}}$ & 0.46 \\
\hline $\mathrm{C}_{15: 0}$ & $1.65^{\mathrm{a}}$ & $1.48^{\mathrm{b}}$ & $1.71^{\mathrm{a}}$ & $1.41^{\mathrm{b}}$ & 0.09 \\
\hline $\mathrm{C}_{16: 0}$ & $31.00^{\mathrm{a}}$ & $26.58^{\mathrm{b}}$ & $31.40^{\mathrm{a}}$ & $31.23^{\mathrm{a}}$ & 0.94 \\
\hline $\mathrm{C}_{16: 1}$ & $1.68^{\mathrm{a}}$ & $1.26^{\mathrm{b}}$ & $1.29^{\mathrm{b}}$ & $1.41^{\mathrm{b}}$ & 0.11 \\
\hline $\mathrm{C}_{17: 0}$ & $1.45^{\mathrm{b}}$ & $1.62^{\mathrm{a}}$ & $1.54^{\mathrm{ab}}$ & $1.40^{\mathrm{b}}$ & 0.07 \\
\hline $\mathrm{C}_{17: 1}$ & 0.30 & 0.33 & 0.30 & 0.31 & 0.02 \\
\hline $\mathrm{C}_{18: 0}$ & $7.37^{\mathrm{b}}$ & $9.47^{\mathrm{a}}$ & $8.42^{\mathrm{ab}}$ & $8.34^{\mathrm{ab}}$ & 0.63 \\
\hline $\mathrm{C}_{18: 1}$ & 20.05 & 20.33 & 19.27 & 19.52 & 0.87 \\
\hline $\mathrm{C}_{18: 2}$ & $2.45^{\mathrm{b}}$ & $2.95^{\mathrm{a}}$ & $2.49^{\mathrm{b}}$ & $2.49^{\mathrm{b}}$ & 0.11 \\
\hline $\mathrm{C}_{18.3}$ & $1.14^{\mathrm{b}}$ & $1.43^{\mathrm{a}}$ & $1.30^{\mathrm{ab}}$ & $1.13^{\mathrm{b}}$ & 0.09 \\
\hline $\mathrm{C}_{18: 2}$ cis- 9 , trans-11 (CLA) & $0.78^{\mathrm{a}}$ & $0.62^{\mathrm{b}}$ & $0.66^{\mathrm{b}}$ & $0.60^{\mathrm{b}}$ & 0.04 \\
\hline \multicolumn{6}{|l|}{ Desaturase index ${ }^{3}$} \\
\hline $\mathrm{C}_{16: 1} / \mathrm{C}_{16: 0}$ & $0.054^{\mathrm{a}}$ & $0.048^{\mathrm{b}}$ & $0.041^{\mathrm{b}}$ & $0.045^{\mathrm{b}}$ & 0.003 \\
\hline $\mathrm{C}_{18: 1} / \mathrm{C}_{18: 0}$ & $2.80^{\mathrm{a}}$ & $2.20^{\mathrm{b}}$ & $2.36^{\mathrm{b}}$ & $2.39^{\mathrm{b}}$ & 0.18 \\
\hline Atherogenicity index ${ }^{4}$ & $3.12^{\mathrm{a}}$ & $2.76^{\mathrm{b}}$ & $3.16^{\mathrm{a}}$ & $3.13^{\mathrm{a}}$ & 0.16 \\
\hline
\end{tabular}

${ }^{\mathrm{a}, \mathrm{b}}$ Means with different superscripts within row differ $(P<0.05)$.

${ }^{1} \mathrm{Wk} 10$ of pregnancy for 12 -mo kidding interval.

${ }^{2} \mathrm{Wk} 5$ of the subsequent lactation.

${ }^{3}$ According to Perfield et al. (2002).

${ }^{4}(\mathrm{C} 12+\mathrm{C} 14+\mathrm{C} 16) /$ sum of unsaturated fatty acids (from Ulbricht and Southgate, 1991).

K24 goats suggests a lower number of secretory cells in the udder of K24 goats.

During pregnancy in the subsequent lactation (wk 80 to 92), milk composition and SCC did not differ between groups on average: fat, $4.85 \pm 0.24 \%$; protein, $3.97 \pm$ $0.13 \%$; lactose, $4.13 \pm 0.06 \%$; and $\log _{10}$ SCC, $6.32 \pm 0.10$.

Throughout the study, milk SCC exceeded the limit of $1 \times 10^{6}$ cells $/ \mathrm{mL}$ except for $\mathrm{K} 12$ at wk 52 (wk 2 of subsequent lactation). The SCC values were slightly higher than those previously reported by Salama et al. (2003) in the same breed milked once daily. This greater content of SCC seems to be due to a parity effect rather than an effect of once-daily milking. All goats in the current study were multiparous, and Salama et al. (2003) reported an increase in milk SCC as parity number increased, with no difference in SCC between goats milked once- or twice-daily.

\section{Fatty Acid Profile of Milk Fat}

Only minor differences in FA profile were observed between K12 and K24 goats at wk 39 (wk 10 of pregnancy), when milk fat of K12 goats contained greater $(P<0.05)$ palmitoleic $\left(\mathrm{C}_{16: 1}\right)$ and the cis-9,trans-11 iso- mer of conjugated linoleic acid (CLA) than K24 goats (Table 2$)$. The CLA $\left(\mathrm{C}_{18: 2}\right.$ cis-9,trans-11) is synthesized in the rumen and is also produced in the mammary gland by $\Delta^{9}$-desaturase; its increase in dairy products is considered desirable (McGuire and McGuire, 1999). An increase $(P<0.05)$ in the $\mathrm{C}_{16: 1} / \mathrm{C}_{16: 0}$ and $\mathrm{C}_{18: 1} / \mathrm{C}_{18: 0}$ desaturase indices, related to the activity of the $\Delta^{9}$ desaturase enzyme (Perfield et al., 2002; Kelsey et al., 2003), was observed in the milk of K12 goats compared with that of K24 goats (Table 2). Consequently, the CLA content in milk of K12 goats was $18.2 \%$ greater $(P<0.05)$ than that of K24 goats but only at wk 39 .

At wk 55 (wk 5 of subsequent lactation) more FA differences between groups were observed $(P<0.05)$. Thus, milk fat from K12 goats contained higher levels of caproic $\left(\mathrm{C}_{6: 0}\right)$, caprylic $\left(\mathrm{C}_{8: 0}\right)$, capric $\left(\mathrm{C}_{10: 0}\right)$, margaric $\left(\mathrm{C}_{17: 0}\right)$, linoleic $\left(\mathrm{C}_{18: 2}\right)$, and linolenic $\left(\mathrm{C}_{18: 3}\right)$, and lower palmitic $\left(\mathrm{C}_{16: 0}\right)$ and $\mathrm{C}_{16: 1}$ than K24 goats (Table 2). The effect was more marked in $\mathrm{C}_{16: 0}(17.5 \%)$ that correlates negatively with $\mathrm{C} 4$ to $\mathrm{C} 8$ (Chilliard et al., 2003), in agreement with the greater percentages of these shortchain FA in the milk of K12 goats at wk 55. Human diets rich in $\mathrm{C}_{12: 0}, \mathrm{C}_{14: 0}$, and $\mathrm{C}_{16: 0} \mathrm{FA}$ are potentially hypercholesterolemic, whereas $\mathrm{C}_{18: 0}$ and unsaturated 
long chain FA have cholesterol-lowering and antiatherogenic properties (Ney, 1991). In our results, the atherogenicity index in K12 was lower $(P<0.05)$ than in $\mathrm{K} 24$ at wk 55 (wk 5 of subsequent lactation) when $\mathrm{C}_{16: 0}$ percentages were low and polyunsaturated $\mathrm{FA}\left(\mathrm{C}_{18: 2}\right.$ and $\mathrm{C}_{18: 3}$ ) were high (Table 2 ).

Stage of lactation markedly affected the FA profile of milk fat in $\mathrm{K} 12$ goats as previously reported by Schmidely et al. (2002). Milk fat of K12 goats at wk 39 (wk 10 of pregnancy) or in late lactation contained greater $(P<0.05)$ percentages of myristic $\left(\mathrm{C}_{14: 0}\right)$, pentadecanoic $\left(\mathrm{C}_{15: 0}\right), \mathrm{C}_{16: 0}$, and $\mathrm{C}_{16: 1}$, and lower $(P<0.05)$ $\mathrm{C}_{6: 0}, \mathrm{C}_{8: 0}, \mathrm{C}_{10: 0}, \mathrm{C}_{17: 0}$, stearic $\left(\mathrm{C}_{18: 0}\right), \mathrm{C}_{18: 2}$, and $\mathrm{C}_{18: 3}$ acids than did milk fat at wk 55 (wk 5 of subsequent lactation) or in early lactation. The greater long chain FA $\left(\mathrm{C}_{18}\right)$ percentages at wk 55 (wk 5 of subsequent lactation) could be a consequence of the mobilization of body reserves during the negative energy balance in early lactation, as indicated previously during early lactation in dairy goats (Schmidely et al., 2002). Negative correlation exists between $\mathrm{C}_{18}$ and medium-chain FA in milk fat of dairy goats (Chilliard et al., 2003) as found in our results for the same FA in the milk of K12 goats at wk 5 of the subsequent lactation (Table 2). The CLA concentration in milk fat of K12 was greater $(P<0.05)$ at wk 39 than at wk 55, in agreement with the greater desaturase activity observed at wk 39 . Moreover, the secretion of polyunsaturated FA, known as inhibitors of desaturase activity (Chilliard et al., 2003), was lowest $(P<0.05)$ at wk 39 in K12 goats. We are not aware of any previous research on the effect of lactation stage on CLA or desaturase index in goat milk. Similar to our results, a small, but significant increase in milk fat content of CLA and desaturase index as lactation advanced was reported in dairy cows (Kelsey et al., 2003), but Stanton et al. (1997) found no effect of lactation stage on milk fat CLA levels in dairy cows.

On the contrary, the FA concentrations of milk fat in K24 goats were unchanged between wk 39 and 55 except for pentadecanoic $\left(\mathrm{C}_{15: 0}\right)$ acid, which was greater $(P<0.05)$ at wk 39 (Table 2$)$. This may be a consequence of the unchanged physiological stage during extended lactation, and of the steady state of nutrition despite probable seasonal changes in the quality of pasture.

\section{Milk Fractions in the Udder}

Yield of milk fractions. Figure 3 shows milk partitioning and milk accumulation rates in the alveolar and cisternal udder compartments in K12 and K24 goats. Percentages of cisternal milk varied according to lactation wk (58 to $82 \%$ ) and agreed with values previously reported in Murciano-Granadina dairy goats (Salama et al., 2004).
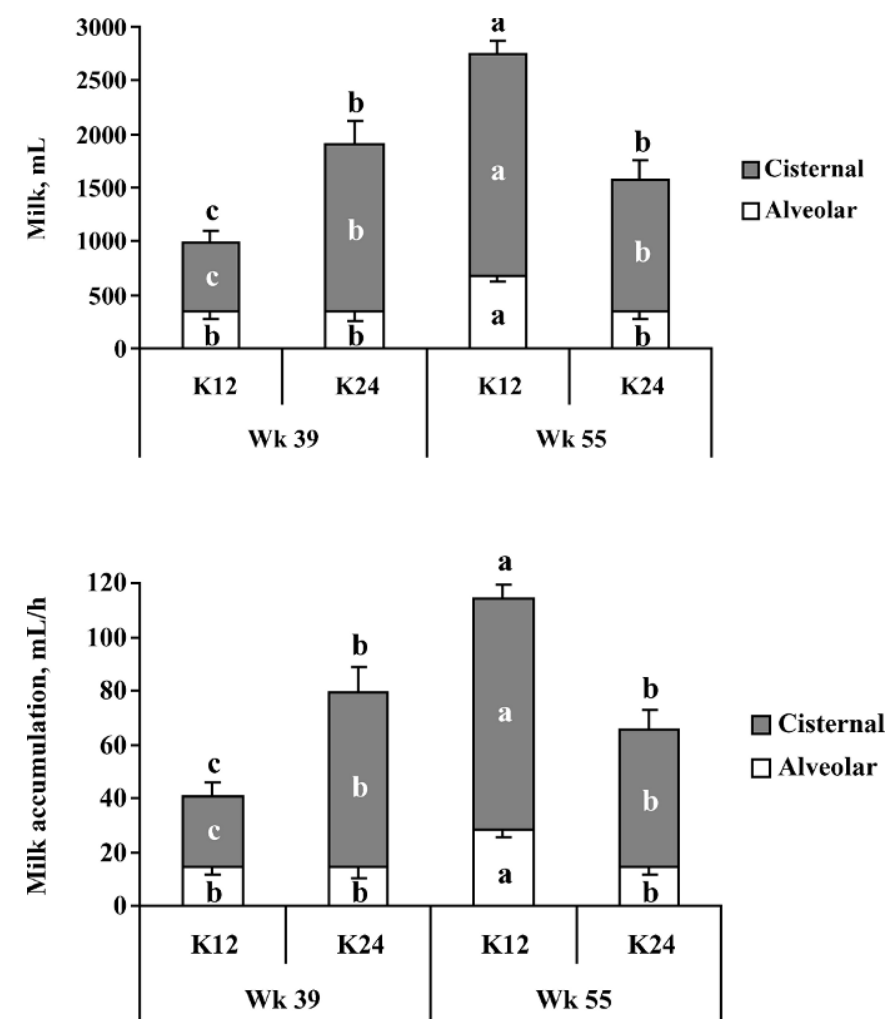

Figure 3. Milk partitioning (upper panel) and milk accumulation rates (lower panel) in the udder of dairy goats kidded annually (K12) or biennially (K24). Measurements were carried out at wk 39 (wk 10 of pregnancy) and 55 (wk 5 of subsequent lactation) of lactation. Values are least squares means with SE indicated by vertical bars. a,b,c Different means $(P<0.05)$ are indicated by different letters.

At wk 39 (wk 10 of pregnancy), K12 goats had lower $(P<0.05)$ total milk $(975 \pm 167$ vs. $1912 \pm 270 \mathrm{~mL})$, cisternal milk ( $638 \pm 126$ vs. $1560 \pm 214 \mathrm{~mL}$ ), and percentage of cisternal milk ( $57.7 \pm 4.0$ vs. $82.1 \pm 6.2 \%)$ than K24 open goats. Nevertheless, volume of alveolar milk was similar for K12 and K24 goats and averaged $345 \pm 78 \mathrm{~mL}$.

At wk 55 (wk 5 of subsequent lactation), milk yield of K12 goats peaked after kidding and the volume of cisternal milk tripled $(P<0.001)$ its value at wk 39 , whereas volume of alveolar milk only doubled $(P<$ 0.001 ) as shown in Figure 3. Volumes of cisternal and alveolar milk at wk 55 in K12 goats were greater $(P<$ 0.01 ) than in K24 goats, without differences in cisternal milk percentages. In contrast to K12 goats, K24 goats were in a similar physiological stage between wk 39 and 55 and their milk yields remained similar across that period; thus, volumes of cisternal and alveolar milk, as well as cisternal milk percentages, remained unchanged. These results indicate the main role of the cistern for accommodating the udder to changes in milk yield (i.e., K12 goats at early lactation). This conclusion 
Table 3. Effect of kidding interval and lactation stage on composition of milk fractions in dairy goats (data are least squares means).

\begin{tabular}{|c|c|c|c|c|c|}
\hline \multirow[b]{3}{*}{ Item } & \multicolumn{4}{|c|}{ Kidding interval, mo } & \multirow[b]{3}{*}{ SEM } \\
\hline & \multicolumn{2}{|c|}{12} & \multicolumn{2}{|c|}{24} & \\
\hline & Wk $39^{1}$ & Wk $55^{2}$ & Wk 39 & Wk 55 & \\
\hline Goats, $\mathrm{n}$ & 16 & 16 & 14 & 14 & \\
\hline \multicolumn{6}{|l|}{ Fat, \% } \\
\hline Cisternal & $4.97^{\mathrm{a}}$ & $3.83^{\mathrm{bc}, \mathrm{z}}$ & $3.02^{\mathrm{c}, \mathrm{z}}$ & $4.38^{\mathrm{ab}, \mathrm{z}}$ & 0.66 \\
\hline Alveolar & $5.58^{\mathrm{bc}}$ & $7.36^{\mathrm{a}, \mathrm{y}}$ & $5.01^{\mathrm{c}, \mathrm{y}}$ & $6.18^{\mathrm{b}, \mathrm{y}}$ & 0.65 \\
\hline SEM & 0.48 & 0.45 & 0.54 & 0.55 & - \\
\hline \multicolumn{6}{|l|}{ Protein, \% } \\
\hline Cisternal & $4.70^{\mathrm{a}}$ & $3.26^{\mathrm{b}}$ & $3.02^{\mathrm{b}}$ & $3.64^{\mathrm{b}}$ & 0.42 \\
\hline Alveolar & $4.99^{\mathrm{a}}$ & $3.13^{\mathrm{b}}$ & $3.00^{\mathrm{b}}$ & $3.69^{\mathrm{b}}$ & 0.44 \\
\hline SEM & 0.31 & 0.29 & 0.35 & 0.35 & - \\
\hline \multicolumn{6}{|l|}{ Lactose, \% } \\
\hline Cisternal & $4.22^{\mathrm{b}}$ & $4.47^{\mathrm{a}}$ & $4.35^{\mathrm{ab}}$ & $4.28^{\mathrm{ab}}$ & 0.11 \\
\hline Alveolar & $4.20^{\mathrm{b}}$ & $4.42^{\mathrm{a}}$ & $4.34^{\mathrm{ab}}$ & $4.33^{\mathrm{ab}}$ & 0.09 \\
\hline SEM & 0.08 & 0.08 & 0.09 & 0.10 & - \\
\hline \multicolumn{6}{|c|}{$\mathrm{SCC}, \log _{10} / \mathrm{mL}$} \\
\hline Cisternal & $6.38^{\mathrm{a}}$ & $5.84^{\mathrm{b}, \mathrm{y}}$ & $6.29^{\mathrm{a}}$ & $6.41^{\mathrm{a}}$ & 0.19 \\
\hline Alveolar & $6.41^{\mathrm{a}}$ & $6.09^{\mathrm{b}, \mathrm{z}}$ & $6.34^{\mathrm{ab}}$ & $6.47^{\mathrm{a}}$ & 0.19 \\
\hline SEM & 0.13 & 0.12 & 0.15 & 0.15 & - \\
\hline
\end{tabular}

is supported by the fact that milk accumulation rates were less marked in the alveolar than in the cisternal compartment for both goat groups (Figure 3). Expected differences in cisternal milk between groups should be lower with twice-daily milking, according to the results obtained by Salama et al. (2004) in the same breed.

With regard to the effects of stage of lactation on udder compartments, lower $(P<0.001)$ volume and percentage of cisternal milk were observed in K12 goats in late lactation when compared with their own values in early lactation (Figure 3). Although no data were available on volume and percentage of cisternal milk in K24 goats in early lactation, a reduction in this udder compartment was expected as milk yield decreased. Caja et al. (2004) reported (in dairy cows) that volume of cisternal milk decreased, whereas its proportion increased, as lactation advanced. The difference between goats and cows could be due to the larger cisternal compartment in goats compared with cows, as indicated by Salama et al. (2004). The effect of pregnancy on cisternal milk volume was attributed to a decrease in the nutrients available for milk synthesis, as discussed above, resulting in a decrease in milk yield.

Composition of milk fractions. No references are available on the composition of alveolar and cisternal milk fractions in dairy goats. Alveolar milk contained more $(P<0.001)$ fat than cisternal milk, except for K12 goats at wk 39 (wk 10 of pregnancy) when milk yield was very low (Table 3 ). Similar results were reported in dairy cows (Ayadi et al., 2004) and ewes (McKusick et al., 2002). Milk fat globules are large and do not pass freely from alveoli to cistern, and therefore more fat is retained in the alveolar compartment (McKusick et al., 2002; Ayadi et al., 2004). This emphasizes the importance of milk ejection and complete milking for recovery of milk that is rich in fat.

No differences in protein and lactose content between cisternal and alveolar milk were observed (Table 3). Differences between alveolar and cisternal concentrations of milk protein and lactose are minimal in dairy cows (Ayadi et al., 2004) and dairy ewes (McKusick et al., 2002). Milk protein is found primarily in the form of small casein micelles (Cowie and Tindal, 1971) and therefore can pass freely between alveolar and cisternal compartments between milkings, resulting in minimal differences in protein concentrations of milk fractions. Synthesis of protein and lactose is synergistic and regulated by a final shared metabolic pathway (Fitzgerald et al., 1970), thus it is expected that both components change similarly.

Cisternal and alveolar SCC were similar for open and pregnant goats at wk 39 (Table 3). However, cisternal SCC was lower $(P<0.05)$ than alveolar SCC at wk 55 (wk 5 of subsequent lactation) for K12 goats. This result is consistent with lower SCC in foremilk compared with stripped milk in dairy ewes (Peris et al., 1991) and dairy cows (Bruckmaier et al., 2004). Nevertheless, Ontsouka et al. (2003) found no differences in SCC between milk 
fractions in dairy cows. The difference between cisternal and alveolar SCC observed in early lactating goats in our study reflects the importance of the methodology of milk sampling for SCC determination. Usually, foremilk samples are taken for SCC determination and udder health monitoring in dairy goats. Thus, these samples may not reflect the actual SCC in the total milk at the end of milking.

\section{CONCLUSIONS}

Pregnancy caused a dramatic milk yield drop in dairy goats, which was observable from the second month after mating, and which facilitates drying off before the next kidding. When mating was not done, goats machine-milked once daily under semiextensive conditions lactated for $2 \mathrm{yr}$ consecutively without significant losses in milk yield. Because milk of K24 goats contained more fat and protein with no significant increase in SCC, reduced revenue due to kid crop loss could be partially offset if payment for milk was based on milk quality. Extended lactation may be a useful strategy for reducing goat stress throughout their life span in compromised conditions due to high milk yield or low nutritive resources.

\section{ACKNOWLEDGMENTS}

This work is part of CICYT research project (AGL2002-03472) and was supported by a research scholarship to A. A. K. Salama from the Agencia Española de Cooperación Internacional (AECI) and the Universitat Autònoma de Barcelona (UAB). The authors are grateful to Ramon Costa and the team of the S1GCE (Servei de Granges i Camps Experimentals) of the UAB for the care of the animals, and to Nic Aldam for reviewing the manuscript.

\section{REFERENCES}

Akers, R. M. 2002. Lactation and the mammary gland. 1st ed. Iowa State Press, Ames, Iowa.

Amoah, E. A., S. Gelaye, P. Guthrie, and C. E. Rexroad, Jr. 1996. Breeding season and aspects of reproduction of female goats. J. Anim. Sci. 74:723-728.

Arbel, R., Y. Bigun, E. Ezra, H. Sturman, and D. Hojman. 2001. The effect of extended calving intervals in high lactating cows on milk production and profitability. J. Dairy Sci. 84:600-608.

Athie, F., K. C. Bachman, K. K. Head, M. J. Hayen, and C. J. Wilcox. 1997. Milk plasmin during bovine mammary involution that has been accelerated by estrogen. J. Dairy Sci. 80:1561-1568.

Ayadi, M., G. Caja, X. Such, M. Rovai, and E. Albanell. 2004. Effects of different milking intervals on the composition of cisternal and alveolar milk in dairy cows. J. Dairy Res. 71:304-310.

Bachman, K. C., M. J. Hayen, D. Morse, and C. J. Wilcox. 1988. Effect of pregnancy, milk yield, and somatic cell count on bovine milk fat hydrolysis. J. Dairy Sci. 71:925-931.

Bell, A. W., R. Slepetis, and R. A. Ehrhardt. 1995. Growth and accretion of energy and protein in the gravid uterus during late pregnancy in Holstein cows. J. Dairy Sci. 78:1954-1961.
Bormann, J., G. R. Wiggans, T. Druet, and N. Gengler. 2002. Estimating effects of permanent environment, lactation stage, age, and pregnancy on test-day yield. J. Dairy Sci. 85(Jan.). Online. Available at: http://www.adsa.org/jds/papers/2002/d0210263.pdf.

Brotherstone, S., R. Thompson, and I. M. S. White. 2004. Effects of pregnancy on daily milk yield of Holstein-Friesian dairy cattle. Livest. Prod. Sci. 87:265-269.

Bruckmaier, R. M., D. Weiss, M. Wiedemann, S. Schmitz, and G. Wendl. 2004. Changes of physicochemical indicators during mastitis and the effects of milk ejection on their sensitivity. J. Dairy Res. 71:316-321.

Caja, G., M. Ayadi, and C. H. Knight. 2004. Changes in cisternal compartment based on stage of lactation and time since milk ejection in the udder of dairy cows. J. Dairy Sci. 87:2409-2415.

Chilliard, Y., A. Ferlay, J. Rouel, and G. Lamberet. 2003. A review of nutritional and physiological factors affecting goat milk lipid synthesis and lipolysis. J. Dairy Sci. 86:1751-1770.

Cowie, A. T., and J. S. Tindal. 1971. The Physiology of Lactation. Camelot Press Ltd., London, UK.

Dahl, G. E., and D. Petitclerc. 2003. Management of photoperiod in the dairy herd for improved production and health. J. Anim. Sci. 81(Suppl. 3):11-17.

Dhindsa, D. S., J. Metcalfe, and J. A. Resko. 1981. Oestrogen concentrations in systemic plasma of pregnant pygmy goats. J. Reprod. Fertil. 62:99-103.

Falagan, A. 1988. Caracterización productiva de la raza caprina Murciano-Granadina en la región de Murcia: Aspectos técnicos y sociales. Instituto Nacional de Investigaciones Agrarias, Madrid, Spain.

Fitzgerald, D. K., U. Brodbeck, I. Kiyosawa, R. Mawal, B. Colvin, and K. E. Ebner. 1970. $\alpha$-Lactalbumin and the lactose synthetase reaction. J. Biol. Chem. 245:2103-2108.

Freetly, H. C., and C. L. Ferrell. 1998. Net flux of glucose, lactate, volatile fatty acids, and nitrogen metabolites across the portaldrained viscera and liver of pregnant ewes. J. Anim. Sci. 76:3133-3145.

Kelsey, J. A., B. A. Corl, R. J. Collier, and D. E. Bauman. 2003. The effect of breed, parity, and stage of lactation on conjugated linoleic acid (CLA) in milk fat from dairy cows. J. Dairy Sci. 86:2588-2597.

Khan, J. R., and R. S. Lurdi. 2002. Changes in blood glucose, plasma non-esterified fatty acids and insulin in pregnant and non-pregnant goats. Trop. Anim. Health Prod. 34:81-90.

Knight, C. H. 1997. Biological control of lactation length. Livest. Prod. Sci. 50:1-3.

Knight, C. H., and C. J. Wilde. 1988. Milk production in concurrently pregnant and lactating goats mated out of season. J. Dairy Res. 55:487-493.

Knight, C. H., and C. J. Wilde. 1993. Mammary cell changes during pregnancy and lactation. Livest. Prod. Sci. 35:3-19.

Kornalijnslijper, J. E., B. Kemp, M. M. Bevers, H. A. Van Oord, and M. A. M. Taverne. 1997. Plasma prolactin, growth hormone and progesterone concentrations in pseudopregnant, hysterectomized and pregnant goats. Anim. Reprod. Sci. 49:169-178.

Kramer, J. K. C., V. Fellner, M. E. R. Dugan, F. D. Sauer, M. M. Mossoba, and M. P. Yurawecz. 1997. Evaluating acid and base catalysts in the methylation of milk and rumen fatty acids with special emphasis on conjugated dienes and total trans fatty acids. Lipids 32:1219-1228.

Linzell, J. L. 1973. Innate seasonal oscillations in the rate of milk secretion in goats. J. Physiol. 230:225-233.

Mackenzie, D. 1967. Goat husbandry. Faber and Faber, London, UK.

Manalu, W., M. Y. Sumaryadi, and N. Kusumorini. 1996. Effect of fetal number on the concentrations of circulating maternal serum progesterone and estradiol of does during late pregnancy. Small Rumin. Res. 23:117-124.

McGuire, M. A., and M. K. McGuire. 1999. Conjugated linoleic acid (CLA): A ruminant fatty acid with beneficial effects on human health. Proc. Am. Soc. Anim. Sci. 1999. Online. Available http:// www.asas.org/JAS/symposia/proceedings/0938.pdf.

McKusick, B. C., D. L. Thomas, Y. M. Berger, and P. G. Marnet. 2002. Effect of milking interval on alveolar versus cisternal milk 
accumulation and milk production and composition in dairy ewes. J. Dairy Sci. 85:2197-2206.

Mellado, M., N. Y. Avila, and E. García. 1998. Estrous synchronization with norgestomet and estradiol valerate at the end of lactation accelerates drying off in goats. Small Rumin. Res. 31:61-66.

Ney, D. M. 1991. Potential for enhancing the nutritional properties of milk fat. J. Dairy Sci. 74:4002-4012.

Nguyen, D. A., A. F. Parlow, and M. C. Neville. 2001. Hormonal regulation of tight junction closure in the mouse mammary epithelium during the transition from pregnancy to lactation. J. Endocrinol. 170:347-356.

Olori, V. E., S. Brotherstone, W. G. Hill, and B. J. McGuirk. 1997. Effect of gestation stage on milk yield and composition in Holstein Friesian dairy cattle. Livest. Prod. Sci. 52:167-176.

Ontsouka, C. E., R. M. Bruckmaier, and J. W. Blum. 2003. Fractionized milk composition during removal of colostrums and mature milk. J. Dairy Sci. 86:2005-2011.

Osterman, S., and J. Bertilsson. 2003. Extended calving interval in combination with milking two or three times per day: Effects on milk production and milk composition. Livest. Prod. Sci. 82:139-149.

Peaker, M., and J. L. Linzell. 1974. The effects of oestrus and exogenous oestrogen on milk secretion in the goat. J. Endocrinol. 61:231-240.

Perfield, J. W., G. Bernal-Santos, T. R. Overton, and D. E. Bauman. 2002. Effects of dietary supplementation of rumen-protected conjugated linoleic acid in dairy cows during established lactation. J. Dairy Sci. 85:2609-2617.

Peris, C., P. Molina, N. Fernandez, M. Rodriguiz, and A. Torres. 1991. Variation in somatic cell count, California mastitis test, and electrical conductivity among various fractions of ewe's milk. J. Dairy Sci. 74:1553-1560.
Ratnayake, D. R., B. Berglund, J. Bertilsson, M. Forsberg, and H. Gustafsson. 1998. Fertility in dairy cows managed for calving intervals of 12,15 or 18 months. Acta Vet. Scand. 39:215-228.

Remond, B., A. Ollier, and G. Miranda. 1992. Milking of cows in late pregnancy: milk production during this period and during the succeeding lactation. J. Dairy Res. 59:233-241.

Salama, A. A. K., G. Caja, X. Such, S. Peris, A. Sorensen, and C. H. Knight. 2004. Changes in cisternal udder compartment induced by milking interval in dairy goats milked once- or twice-daily. J. Dairy Sci. 87:1181-1187.

Salama, A. A. K., X. Such, G. Caja, M. Rovai, R. Casals, E. Albanell, M. P. Marin, and A. Marti. 2003. Effects of once versus twice daily milking throughout lactation on milk yield and milk composition in dairy goats. J. Dairy Sci. 86:1673-1680.

Schmidely, Ph., F. Meschy, J. Tessier, and D. Sauvant. 2002. Lactation response and nitrogen, calcium, and phosphorus utilization of dairy goats differing by the genotype for $\alpha_{\mathrm{s} 1}$-casein in milk, and fed diets varying in crude protein concentration. J. Dairy Sci. 85:2299-2307.

Sorensen, A., and C. H. Knight. 2002. Endocrine profiles of cows undergoing extended lactation in relation to the control of lactation persistency. Domest. Anim. Endocrinol. 23:111-123.

Stanton, C., F. Lawless, G. Kjellmer, D. Harrington, R. Devery, J. F. Connolly, and J. Murphy. 1997. Dietary influences on bovine milk cis-9, trans-11 conjugated linoleic acid content. J. Food Sci. 62:1083-1086.

Stelwagen, K., V. C. Farr, S. R. Davis, and C. G. Prosser. 1995. EGTAinduced disruption of epithelial cell tight junctions in the lactating caprine mammary gland. Am. J. Physiol. 269:R848-R855.

Sukhija, P. S., and D. L. Palmquist. 1988. Rapid method for determination of total fatty acid content and composition of feedstuffs and feces. J. Agric. Food Chem. 36:1202-1206.

Ulbricht, T. L. V., and D. A. T. Southgate. 1991. Coronary heart disease: Seven dietary factors. Lancet 338:985-992. 